\title{
Comparative Analysis of Digital Governance Practices of the Leading Countries in the Field of Socio-economic Regulation
}

\author{
Angelina Nevzorova ${ }^{1, *}$ Aleksandr Volodin ${ }^{1}$ Maxim Ivanov $^{1}$ \\ ${ }_{1}^{1}$ Institute of Industrial Management, Peter the Great Saint-Petersburg Polytechnic University, Saint Petersburg 195251, \\ Russian Federation \\ ${ }^{*}$ Corresponding author. Email: ne.angelina.ne@yandex.ru
}

\begin{abstract}
The article is devoted to comparative socio-economic analysis of Russia with such foreign countries as Denmark, Norway, the United States of America, which are leaders in social and economic development of the population. The first part of the work provides a summary of the socio-economic situation of the countries, which reflects the situation of these countries on the world stage in the field of socio-economic indicators. The second part presents the mechanisms used in the social and economic policy of the states under study, after which their impact on the situation in Russia is analyzed. Based on the comparative analysis it is concluded about the most promising mechanisms that can be applied in Russia, as in the country with the largest number of low indicators considered in the study.
\end{abstract}

Keywords: Economic analysis, socio-economic development, public administration, regional economy, state regulation, foreign countries.

\section{INTRODUCTION}

The state regulatory impact, in many respects, was and remains practically the only mechanism of real influence on the socio-economic situation in society, ensuring the interests of this society in terms of social benefits and guarantees. It should be noted that most commercial companies, including those with state participation, which is typical for Russia, pursue the interests of obtaining profits and super-profits, which negatively affects the socio-economic situation of society. Thus, commercial enterprises often indirectly create the prerequisites for widening the social gap with their own interest in enrichment. Citizens themselves, without proper unification, are not able to withstand these negative consequences of a market economy. In such conditions, the state acts as a certain referee, as a mechanism for balancing these interests of business and population.

In some states, this mechanism of state regulation of economic interests creates the necessary conditions for improving public life, the development of socioeconomic processes in the national economy and the growth of its effectiveness, and in some it entails a social gap in the population. This study is devoted to the analysis of socio-economic regulation practices in different countries, with different types of state regulation and a balance of interests.

The aim of the work is to identify the most promising typical mechanisms of state regulation of socioeconomic development. As a hypothesis put forward in this paper, we put forward the opportunity, having ana- lyzed the most promising countries in terms of social and economic efficiency, to develop the most effective practices of state socio-economic regulation.

\section{LITERATURE REVIEW}

Issues of socio-economic development of the state in the scientific literature are often raised [1-3]. Many works are devoted to the search for additional ways to increase economic efficiency among the reasons that can ensure economic growth through the social sphere, human development is highlighted [4] and improvement of the housing stock. In addition, such studies often focus on neural networks, ex ante and ex post approach and others. Economic modeling is currently a very common phenomenon that helps to effectively predict the future development of the state. Moreover, the developed socio-economic models can be used in environmental assessments. It should also be noted that today many economic and mathematical models have been formed to improve the socio-economic situation of various territories of the Russian Federation through innovation [5]. In the scientific literature, the social development of citizens is singled out to create balanced demand in the economic system [6], [7]. At the same time, a lot of work has been devoted to the issues of digitalization rooting in society [8], which discusses the positive aspects and effectiveness of digital banking, based on the path of economic efficiency of the state. However, the inclusion of the digital component in economic assessments mainly comes down to the use of digitalization at the level of enterprises of various kinds [9], or to the use of digitalization to assess the 
capitalization of companies, or how Gromova does in its work. EA - the use of digitalization elements to assess the development of the automotive industry in Russia [10].

Thus, most of the work comes down to the economic effect of companies and corporations, and only in certain cases - regions and countries [11]. In many works, the factor of the complexity of the analysis of this problem is also not considered, which will be leveled in this paper.

\section{METHODOLOGY}

The following countries were selected for comparative analysis. First, it is the United States of America, as the country with the highest absolute value of GDP.
Moreover, according to the OECD, the United States is in fifth place in terms of this indicator per capita, and this state emphasizes economic efficiency in its development. Also, Norway was taken for research, as a country with similar climatic conditions to Russia, but a more progressive standard of living. And Denmark, for the same reasons as countries emphasizing social development [12]. The study also examines Russia, whose political course inclines toward economic liberalism, but with the remnants of the social guarantees of the USSR, of which it is the successor.

The following is a comparative table of indicators of socio-economic development of these countries (Table 1). The United States in this study is a leader in the efficient exploitation of human resources and is included as a trigger to demonstrate the consequences of an overinclination for economic efficiency [13].

Table 1 Comparison of socio-economic indicators of the studied elements of the global and regional economies

\begin{tabular}{|l|c|c|c|c|}
\hline Indicator & Norway & Denmark & USA & Russia \\
\hline $\begin{array}{l}\text { Oil production per capita (bar- } \\
\text { rels / year) }\end{array}$ & 108,7 & 10,8 & 9,7 & 27,8 \\
\hline GDP per capita (US \$, 2018) & 72169,6 & 50642,6 & 59895 & 25749 \\
\hline $\begin{array}{l}\text { Average salary in US dollars } \\
\text { (net) }\end{array}$ & 3868,7 & 3708,9 & 3300 & 564,25 \\
\hline $\begin{array}{l}\text { Relative share of GDP (net) } \\
\text { received by citizens in\% }\end{array}$ & 5,36 & 7,32 & 5,51 & $2,19(7,19$ without \\
PSS*)
\end{tabular}

The share of oil and gas revenues in the budget of the Russian Federation (mineral extraction tax + export customs duties) in 2018 is $35.9 \%$, which is almost an unpleasant indicator, but at the same time it must be fully involved [14].

To calculate GDP, the statistics of the IMF and Rosstat for 2017 were taken. In this case, it should be noted that in the database of state statistics on US GDP. The United States is equal to 25,749 dollars per person [15].
A report on human development was used to measure inequality indicators. 


\section{RESULTS}

Based on these indicators, the situation of Russia was investigated in comparison with the most promising countries in the field of social and economic development on the world stage.

A summary of the economic models described above is presented in Table 2.

Table 2 The Final comparative table of mechanisms socio-economic regulation

\begin{tabular}{|c|c|c|c|c|}
\hline Mechanism & Norway & Denmark & USA & Russia \\
\hline Tax system & $\begin{array}{l}\text { Mostly direct system. } \\
\text { Progressive scale di- } \\
\text { vided into } 4 \text { groups }\end{array}$ & $\begin{array}{l}\text { Progressive taxation } \\
\text { scale. } \\
\text { Many excise taxes on } \\
\text { tea, coffee, products } \\
\text { containing animal fat. }\end{array}$ & $\begin{array}{l}\text { The predominant direct } \\
\text { system. Progressive } \\
\text { scale divided into } 28 \\
\text { groups }\end{array}$ & $\begin{array}{l}\text { The predominant } \\
\text { direct system. Pro- } \\
\text { gressive scale divided } \\
\text { into } 28 \text { groups }\end{array}$ \\
\hline $\begin{array}{c}\text { Citizens Income } \\
\text { Tax } \\
\end{array}$ & $0 / 27 \%+(0 / 9,5 / 13,7 \%)$ & $6,83-51,7 \%$ & $10-56,9 \%$ & $13 \%$ \\
\hline $\begin{array}{c}\text { Social Security } \\
\text { contributions }\end{array}$ & $16 \%$ & $13 \%+10 \%$ from payroll & $\begin{array}{c}7,65 \%+7,65 \% \text { from } \\
\text { payroll } \\
\end{array}$ & $\begin{array}{c}30,2 \%-38,7 \% \text { from } \\
\text { payroll }\end{array}$ \\
\hline Property tax & $\begin{array}{l}2,5 \% \text { from the cost of } 2 \\
\text { and subsequent housing }\end{array}$ & $\begin{array}{l}1-4 \% \text { depending on the } \\
\text { cost }\end{array}$ & $\begin{array}{c}1-4 \% \text { depending on } \\
\text { local and regional taxes }\end{array}$ & $\begin{array}{c}0,1-2 \% \text { depending on } \\
\text { type and cost }\end{array}$ \\
\hline $\begin{array}{l}\text { On income from } \\
\text { deposits, stocks } \\
\text { and bonds }\end{array}$ & $28 \%$ & $\begin{array}{c}27 \text { or } 42 \% \text { with income } \\
\text { over } \$ 7,400 \text { per year }\end{array}$ & $\begin{array}{l}\text { It is taken into account } \\
\text { in the tax on income of } \\
\text { citizens }\end{array}$ & $\begin{array}{c}35 \% \text { from deposits } \\
13 \% \text { of shares }\end{array}$ \\
\hline $\begin{array}{l}\text { Corporate income } \\
\text { tax of persons }\end{array}$ & $28 \%$ & 16 or $32 \%$ & $\begin{array}{c}15 / 25 / 34 / 39 \%+0-12 \% \\
\text { regional and local tax }\end{array}$ & $20 \%$ \\
\hline Value added tax & $25 \%$ & $25 \%$ & $\begin{array}{c}1,76-10,2 \%+\text { local fees } \\
(\sim 5 \%)\end{array}$ & $10 / 20 \%$ \\
\hline $\begin{array}{l}\text { Medicine } \\
\text { financing }\end{array}$ & $\begin{array}{l}\text { Mostly from the state } \\
\text { budget }\end{array}$ & $\begin{array}{l}\text { Mostly from the state } \\
\text { budget }\end{array}$ & $\begin{array}{l}\text { The medicine is pre- } \\
\text { dominantly private; } \\
\text { there are state clinics } \\
\text { under the Medicaid and } \\
\text { Medicare programs } \\
\text { [16]. }\end{array}$ & $\begin{array}{l}\text { Completely state ex- } \\
\text { cept for honey. Drugs } \\
\text { and super expensive } \\
\text { treatments }\end{array}$ \\
\hline $\begin{array}{l}\text { Education } \\
\text { financing }\end{array}$ & $\begin{array}{l}\text { Entirely from the state } \\
\text { budget, except for pre- } \\
\text { school, to which subsi- } \\
\text { dies are extended [17]. }\end{array}$ & $\begin{array}{l}\text { All levels of education } \\
\text { are funded by the state }\end{array}$ & $\begin{array}{l}\text { Preschool education is } \\
\text { mostly paid. } \\
\text { Medium is free. } \\
\text { Higher education is } \\
\text { fully paid with the pos- } \\
\text { sibility of receiving } \\
\text { state assistance [18]. }\end{array}$ & $\begin{array}{l}\text { All levels of educa- } \\
\text { tion are funded by the } \\
\text { state }\end{array}$ \\
\hline
\end{tabular}

It is characteristic that for all economic systems under consideration, interest or interest on late tax payments is set in either direction, that is, if a citizen overpaid taxes [19], this amount is his deposit for which the same percentage is charged as for that the amount that he would not pay.

\section{THE DISCUSSION OF THE RESULTS}

It should be noted that a number of assumptions were made that were inevitable in the analysis of macroeconomic indicators [20]; nevertheless, an attempt was made to verify the available data as accurately as possible, although even many statistical data carry a certain error, which is clearly seen in the indicators of the quintile coefficient of funds. In addition, an error also exists in the translation of national currencies into US dollars [21]. This series of assumptions, although it creates a data error, nevertheless does not conceptually affect the research analytics and does not change the leading positions of the countries under consideration [22].

In addition to the above, it is necessary that the analysis was conducted on a limited number of countries [23], when comparing them in Russia, which can negatively reflect on the conclusions made, although it is worth noting that these countries are the best representatives in their type of development.

\section{CONCLUSIONS}

Thus, based on the study, the following typology of domestic interests can be distinguished, depending on development goals:

1. Development through the social sector of the economy, by increasing domestic demand: 
1.1. Low coefficient of stratification of the population.

1.2. High ratio of tax burden to wages $(29.12 \%$ and $40.63 \%$ on average for a citizen to spend on tax payments) [21], [24].

1.3. Reliance on a direct and progressive taxation scale.

1.4. High property taxes.

1.5. High taxes on income on deposits, stocks and bonds.

1.6. Corporate income tax in the range of one third of earned funds.

1.7. Value added tax is $25 \%$ of the price of the goods [25].

1.8. State financing of medicine and education.

2. The development of economic efficiency, with a focus on foreign markets:

2.1. High coefficient of stratification of the population.

2.2. Low ratio of tax burden to wages (in many respects, this indicator is ensured by the presence of tax deductions).

2.3. Reliance on a direct and progressive taxation scale.

2.4. High property taxes are regulated by each budget level independently [26].

2.5. Accounting for income from deposits, stocks and bonds in the general progressive taxation scale.

2.6. Diversified corporate income tax ending at the rate of $50 \%$ [27].

2.7. Low value added tax.

2.8. State funding exclusively secondary education.

Overall, at the end of this work, we would like to note that an attempt to achieve two fundamentally different interests of social development (economic efficiency of the state and the development of social institutions with their support) can lead to extremely negative consequences for the economy of the country that will deal with this. Currently, Russia is faced with the need for this choice, which it is trying to make in favor of economic efficiency, but at the same time remaining with a large number of social obligations, which significantly slows down both one-way and the other development, without creating the necessary conditions for sustainable social -economic development.

\section{REFERENCES}

[1] A.E. Skhvediani, T.Y. Kudryavtseva, The socioeconomic development of Russia: Some historical aspects, European Research Studies Journal 21(4) (2018) 195207. DOI: https://doi.org/10.35808/ersj/1114

[2] N.I. Didenko, D.F. Skripnuk, O.V. Mirolyubova, Big data and the global economy, in: Proceedings of the $10^{\text {th }}$ International Conference Management of LargeScale System Development (MLSD), IEEE Press, Piscataway, NJ, 2017, pp. 8109611. DOI: https://doi.org/10.1109/MLSD.2017.8109611
[3] D.S. Demidenko, A.A. Gorovoy, E.D. MalevskaiaMalevich, Specifics of indicative macroeconomic planning, in: Proceedings of the $29^{\text {th }}$ International Business Information Management Association Conference Education Excellence and Innovation Management through Vision 2020: From Regional Development Sustainability to Global Economic Growth (IBIMA), IBIMA Publishing, Pennsylvania, USA, 2017, pp. 22222227.

[4] D.G. Rodionov, T.J. Kudryavtseva, A.E. Skhvediani, Human development and income inequality as factors of regional economic growth, European Research Studies Journal 21(2) (2018) 323-337.

[5] M. Ivanova, V. Degtereva, A. Gorovoy, Ex ante and ex post regulatory impact assessment in Russia: framework and practice, in: Proceedings of the 30th International Business Information Management Association Conference- Vision 2020: Sustainable Economic development, Innovation Management, and Global Growth (IBIMA), IBIMA Publishing, Pennsylvania, USA, 2017, pp. 1262-1266.

[6] E. Farvaque, A. Mihailov, A. Naghavi, Grand Experiment of Comunism: Discovering the Trade-Off between Equality and Efficiency, Journal of institutional and theoretical economics 174(4) (2018) 707-742. DOI: https://doi.org/10.1628/jite-2018-0003

[7] O.A. Stroeva, N.V. Mironenko, I.R. Lyapina, E.V. Petrukhina, Peculiarities of formation of socially oriented strategy of economic growth of national economy, European Research Studies Journal 19(2) (2016) 161170. DOI: https://doi.org/10.35808/ersj/531

[8] A.V. Bataev, E.V. Plotnikova, Assessment of digital banks' performance, Revista Espacios 40(20) (2019) 24.

[9] D.S. Demidenko, V.V. Kulibanova, V.G. Maruta, Using the principles of "digital economy" in assessing the company capitalization, in: Proceedings of the 31 st International Business Information Management Association Conference (IBIMA), IBIMA Publishing, Pennsylvania, USA, 2018, pp. 6087-6091.

[10] E.A. Gromova (2019) Digital economy development with an emphasis on automotive industry in Russia Espacios, Revista Espacios 40(06) (2019) 27.

[11] I. A. Rudskaia, Regional innovation system: Formation features and growth areas (case study: St. Petersburg), in: Proceedings of the 30th International Business Information Management Association Conference- Vision 2020: Sustainable Economic development, Innovation Management, and Global Growth (IBIMA), IBIMA Publishing, Pennsylvania, USA, 2017, pp. 541547. 
[12] D. Rodionov, I. Rudskaia, V. Degtereva, Regional foresight as a technology for development of the regional innovation system, in: Proceedings of the 29th International Business Information Management Association Conference - Education Excellence and Innovation Management through Vision 2020: From Regional Development Sustainability to Global Economic Growth, (IBIMA), IBIMA Publishing, Pennsylvania, USA, 2017, pp. 2699-2705.

[13] I. Rudskaia, Regional innovation foresights: drivers and barriers for development, in: Proceedings of the 30th International Business Information Management Association Conference, Vision 2020: Sustainable Economic development, Innovation Management, and Global Growth (IBIMA), IBIMA Publishing, Pennsylvania, USA, 2017, pp. 889-903.

[14] Ministry of Finance of the Russian Federation (2017) Budget for citizens, Structure of federal budget expenditures.

https://www.minfin.ru/common/upload/library/2017/12/ main/BDG_2018_FInAL.pdf Accessed on 21 Jan 2020.

[15] The Federal State Statistics Service.

http://www.gks.ru/ Accessed on 19 Jan 2020.

[16] Central intelligence agency (2016) The world factbook. https://www.cia.gov/library/publications/theworld-factbook/rankorder/2241rank.html Accessed on 15 Jan 2020.

[17] O.V. Zaborovskaia, E.V. Plotnikova, Assessment of the housing stock condition as an element for estimating the conditions for human capital development in the regions of the Russian Federation, in: Proceedings of the 28th International Business Information Management Association Conference - Vision 2020: Innovation Management, Development Sustainability, and Competitive Economic Growth, (IBIMA), IBIMA Publishing, Pennsylvania, USA, 2016, pp. 1218-1225.

[18] International Monetary Fund (2019) World Economic Outlook Database.

https://www.imf.org/external/pubs/ft/weo/2019/01 Accessed 18 Jan 2020.

[19] I. Rudskaya, D. Rodionov, Econometric modeling as a tool for evaluating the performance of regional innovation systems (with regions of the Russian Federation as the example), Academy of Strategic Management Journal, 16(2) (2017) 41.

[20] I.A. Rudskaya, D.G. Rodionov, Comprehensive evaluation of Russian regional innovation system performance using a two-stage econometric model, Revista Espacios, 39(4) (2018) 40.
[21] EMISS state statistics, Russia's GDP per capita at purchasing power parity in US dollars.

https://www.fedstat.ru/indicator/40579 Accessed on 25 Feb 2020.

[22] A.V. Babkin, E.P. Karlina, N.Sh. Epifanova, Neural networks as a tool of forecasting of socioeconomic systems strategic development, in: Proceedings of the 28th International Business Information Management Association Conference - Vision 2020: Innovation Management, Development Sustainability, and Competitive Economic Growth (IBIMA), IBIMA Publishing, Pennsylvania, USA, 2016, pp. 11-17.

[23] EMISS state statistics, Gross regional product per capita in rubles. https://www.fedstat.ru/indicator/42928 11 Feb 2020

[24] Human Development Report (2016) Selim Jahan Statistical AppendiX http://hdr.undp.org/sites/default/files/2016_human_dev elopment_report.pdf Accessed 2 Oct 2020

[25] T.V. Shabunina, S.P. Shchelkina, D.G. Rodionov, An innovative approach to the transformation of ecoeconomic space of a region based on the green economy principles, Academy of Strategic Management Journal 16(1) (2017) 176-185.

[26] T.V. Shabunina, S.P. Shchelkina, D.G. Rodionov, Regional habitat as a factor of the human capital assets development in Russian region, Journal of Social Sciences Research 3 (2018) 313-317. DOI:

https://doi.org/10.32861/jssr.spi3.313.317

[27] A.S. Sokolitsyn, M.V. Ivanov, N.A. Sokolitsyna, Statistic modeling industrial enterprises production process parameters, in: Proceedings of the 30th International Business Information Management Association Conference- Vision 2020: Sustainable Economic development, Innovation Management, and Global Growth (IBIMA), IBIMA Publishing, Pennsylvania, USA, 2017, pp. 1041-1052. 